\title{
Effect of Ozone and Storage Temperature on Postharvest Diseases and Physiology of Carrots (Daucus carota L.)
}

\author{
Chiam L. Liew ${ }^{1}$ and Robert K. Prange ${ }^{2}$ \\ Research Station, Agriculture Canada, Kentville, N.S. B4N 1J5, Canada \\ Additional index words. Daucus carota, Botrytis cinerea, Sclerotinia sclerotiorum, respiration, electrolyte leakage, color
}

\begin{abstract}
Effects of ozone and storage temperature on carrots and two postharvest pathogens-Botrytis cinerea Pers. and Sclerotinia sclerotiorum de Bary-were investigated. Pathogen-inoculated and uninoculated whole carrots were exposed to an ozone concentration of 0 (control), $7.5,15,30$, or $60 \mu \mathrm{l} \cdot \mathrm{liter}^{-1}$. Treatment chambers were flushed with a total flow rate of 0.5 liters $\cdot \mathrm{min}^{-1}$ (air and ozone) for $8 \mathrm{~h}$ daily for 28 days. The experiment was repeated twice at storage temperatures of 2,8 , and 16C. The residual ozone concentration (ozone supplied-exhausted and reacted ozone) increased with ozone supply concentration but was less at higher storage temperatures. A $50 \%$ reduction of daily growth rates of both fungi at the highest ozone concentration indicated that ozone was fungistatic. Carrot respiration rate, electrolyte leakage, and total color differences increased with ozone concentration. Ozone-treated carrots were lighter (higher $L^{*}$ values) and less intense (lower chroma values) in color than control carrots.
\end{abstract}

Watery soft rot (Sclerotinia sclerotiorum) and gray mold (Botrytis cinerea) are common postharvest diseases of carrots. Until recently, growers used the fungicide benomyl to control these storage rots. The manufacturer's withdrawal of benomyl as a postharvest fungicidal dip on carrots has necessitated a search for alternatives; ozone is one potential candidate.

Ozone is the tri-atomic form of oxygen that is unstable and decomposes either spontaneously or after it comes in contact with oxidizable surfaces. Ozone's high oxidation potential (Lide, 1991) makes it an effective disinfectant for poultry hatcheries, poultry chill water, water treatment plants, soft-drink bottling plants, and aquaria water (Guinvarch, 1959; Rosenthal and Wilson, 1987; Sheldon and Brown, 1986; Torricelli, 1959; Whistler and Sheldon, 1989; Yang and Chen, 1979). Since ozone can be easily and economically generated on site, transportation and storage costs are not incurred. Unlike $\mathrm{CO}_{2}$ and $\mathrm{N}$, which are two gases commonly used in storage, ozone has a characteristic odor. For this reason, harmful levels of ozone can be instantly detected and avoided by workers.

Ozone can be applied as a gas or as ozonated water. Reported differences on the effectiveness of ozone as a storage disinfectant may be due to differing application methods or measurements of ozone concentration, treatment period, and pathogen and product sensitivity to ozone. Gibson et al. (1960) and Rice et al. (1983) concluded that ozone is an effective agent for controlling microbial and fungal pathogens in stored produce such as cheese, strawberries, raspberries, currants, bananas, and potatoes. Continuous exposure to $0.05 \mathrm{ppm}$ ozone (gas) effectively killed Escherichia coli after 3 days and Staphylococcus aureus in vitro after 15 days (Kashiwagi et al., 1987). Ogawa et al. (1990) demonstrated that spores of $B$. cinerea on the surface of tomatoes were inactivated by exposure to $3.8 \mathrm{~g}$ of ozone $/ \mathrm{ml}$ of water in $10 \mathrm{~min}$. Other reports,

Received for publication 24 Mar. 1993. Accepted for publication 20 Sept. 1993. This study was supported in part by a fellowship from Acadia Univ., Wolfville, N.S. We thank K.B. McRae (statistician) for advice on experimental planning, statistical analysis, presentation of results, and critical reviews of the manuscript in draft form and P.D. Hildebrand (plant pathologist) for advice and assistance. The cost of publishing this paper was defrayed in part by the payment of page charges. Under postal regulations, this paper therefore must be hereby marked advertisement solely to indicate this fact.

${ }^{1}$ Graduate student.

${ }^{2}$ Postharvest physiologist. however, have suggested that ozone is ineffective in controlling rots on apples, muskmelons, peaches, strawberries, blueberries, and green beans. Ozonated apples, cantaloupes, cranberries, corn kernels, and cereal grains demonstrated more decay or damage than those not ozonated (Barger et al., 1948; Brooks and Csallany, 1978; Naito, 1989; Norton, 1968; Schomer and McCulloch, 1948; Spalding, 1968). The objectives of this study were 1) to determine the residual concentration of ozone, 2) to determine the effect of ozone on the two major storage pathogens of carrots, and 3) to observe ozone-induced changes in carrot physiology and quality during storage.

\section{Methods and Materials}

'Vitabrite' carrots, obtained from a local grower (Berwick, N.S.), were hand-washed and stored at $0 \mathrm{C}$ until use. Crown diameters of the carrots were from 3 to $4 \mathrm{~cm}$.

An ozone generator (Tri-Ox, Swindon, England) was set to produce $76.5 \mu \mathrm{l} \cdot$ liter $^{-1}$ of ozone in air. Air containing ozone at flow rates of 0 (control), $0.05,0.1,0.2$, or 0.4 liters $\mathrm{min}^{-1}$ were blended with compressed air to produce ozone concentrations of $0,7.5,15$, 30 , or $60 \mu \mathrm{l} \cdot \mathrm{liter}{ }^{-1}$, in a total flow of 0.5 liters $\cdot \mathrm{min}^{-1}$ for each treatment. Ozone and compressed air flows were controlled with needle valves (Nupro Co., Willoughby, Ohio). Treatment chambers consisted of air-tight 64-liter polyvinylchloride containers (IPL, St. Damien, Que.) placed in storage rooms set at 2, 8, or 16C. The chambers were flushed continuously for $8 \mathrm{~h}$ daily for 28 days.

Ozone concentrations in the chambers were monitored during the treatment period with an ultraviolet-based detector with a measurement range of 0 to $100 \mu \mathrm{l} \cdot \mathrm{liter}^{-1}$ at $253.7 \mathrm{~nm}$ (ozone analyzer model IN-2000-5; In-USA, Newtonville, Mass.). Values presented in Table 1 represent stable concentrations after $4 \mathrm{~h}$ of treatment.

Disease. Isolates of S. sclerotiorum and B. cinerea were obtained from infected carrots in local storage. Fungal stock cultures and inoculum were maintained on potato dextrose agar (PDA) (Becton-Dickinson, Cockeysville, Md.).

A 1.0-cm-diameter mycelial plug, obtained near the margin of a 4- to 5-day-old fungal culture, was placed in a wound of each carrot $1.0 \pm 0.5 \mathrm{~cm}$ from the crown. The wound was a $1.0-\mathrm{cm}-$ diameter $\times 0.5-\mathrm{cm}$-deep depression created with a $1.0-\mathrm{cm}$-diam- 
eter corkborer. Fungal growth along the length of the carrot was measured once every 7 days for 28 days. A sample of 10 carrots was inoculated separately with each fungus for the 15 combinations of ozone concentration and temperature. The entire experiment was repeated twice.

Physiology. Fifteen carrots from each treatment were monitored for weight loss and color changes over the 28-day test period (initial and final measurements were recorded). Carrot moisture loss was measured as percentage weight loss [(initial weight - final weight)/initial weight $\times 100]$. Initial and final carrot color readings, using Commision International d'Eclairage (CIE) L*, a*, b* color space coordinates, were obtained with a tristimulus colorimeter. The Chroma Meter CR-200 (Minolta, Ramsey, N.J.) has an 8$\mathrm{mm}$-diameter measuring port that uses diffuse illumination and a $0^{\circ}$ viewing angle. The meter was calibrated with a white standard calibration plate. Colorimetric values for hue (color) and chroma (intensity) were calculated as chroma $=\sqrt{ }\left(a^{2}+b^{2}\right)$ and hue $=\cos ^{-}$ ${ }^{1}\left[a / \sqrt{ }\left(a^{2}+b^{2}\right)\right]($ Little, 1975). Total color difference was calculated as $(\Delta \mathrm{E})=\sqrt{ }\left[\left(\mathrm{L}_{\text {fin }}-\mathrm{L}_{\text {ini }}\right)^{2}+\left(\mathrm{a}_{\text {fin }}-\mathrm{a}_{\text {ini }}\right)^{2}+\left(\mathrm{b}_{\text {fin }}-\mathrm{b}_{\text {ini }}\right)^{2}\right]$ (Gnanasekharan et al., 1992). Color measurements were taken between 1 to $2 \mathrm{~cm}$ from the carrot crown for initial and final readings.

After 28 days, five preweighed carrots were selected from each ozone treatment for respiration measurements at $9 \mathrm{C}$. The carrots were placed in Nalgene jars and continuously flushed with 25 to 35 $\mathrm{ml} \cdot \mathrm{min}^{-1}$ of $\mathrm{CO}_{2}$-free air. Carbon dioxide evolution rates were measured daily for 5 days with a gas chromatograph (model 3400; Varian Instruments, Mississauga, Ont.) equipped with a CRT-1 column (Alltech Assn., Guelph, Ont.) and a thermal conductivity detector.

A conductivity meter (Radiometer Conductivity Meter, Copenhagen) was used to measure electrolyte leakage of 5 carrots after the experimental period. Initial electrolyte leakage was determined after a 24-h incubation of $1 \mathrm{~g}$ of carrot peel from each carrot in $20 \mathrm{ml}$ of distilled water at $5 \mathrm{C}$. The water contained $1 \mu \mathrm{l} \cdot \mathrm{liter}^{-1}$ Tween 20 to reduce surface tension (Prange and Lidster, 1991). The peels and bathing solution were then frozen at $-18 \mathrm{C}$ and held for another $24 \mathrm{~h}$ before total conductivity was measured on the thawed solution. Percent total solute leakage was calculated as initial conductivity/final conductivity $\times 100$ (Beckerson and Hofstra, 1980).

The two factors, temperature and ozone concentration, were arranged in a split-plot design and replicated twice. Temperatures were assigned to the storage rooms (main plot), and the ozone concentrations (split plot) were randomized to chambers within each storage room. The results were analyzed using the analysis of variance directive in Genstat 5 (Payne et al., 1988).

A logarithmic $\left(\log _{10}\right)$ transformation was used to stabilize variance of fungal growth rates. Mean log values were back-transformed and are presented in parentheses in Table 2.

\section{Results}

Ozone. The quantitative factor of ozone concentration can be expressed as either supplied or residual ozone concentration. Supplied ozone concentration refers to the ozone concentration provided to the chambers, whereas residual concentration was the ozone concentration measured in a chamber containing experimental carrots (residual concentration $=$ supplied concentration exhausted and reacted ozone) (Table 1).

In this study, residual ozone concentration seemed to be influenced by temperature and supplied ozone concentration (Table 1). It seems that the rate of ozone depletion increased with temperature since higher temperatures produced lower residual ozone concen- trations.

To help identify the influence of ozone concentration at each of the temperatures, regression coefficients of the variate means at the three temperatures have been provided in Tables 2-4. Significant differences in regression coefficients among the treatment temperatures would indicate a different linear effect of ozone concentration for each temperature.

Disease. The fungal inoculum was applied to wounded carrots to ensure disease development. Fungal surface growth included spores, sclerotia and mycelia of $B$. cinerea, and only sclerotia, and mycelia of $S$. sclerotiorum. Both fungi developed in the ozonated environment but exhibited varied mycelial growth rates and surface structure (sclerotia and spores) development on the carrots. At $2 \mathrm{C}$ there were fewer surface structures present with increasing ozone concentration (data not shown). At the highest ozone concentration $\left(60 \mu \mathrm{l} \cdot\right.$ liter $\left.^{-1}\right)$, water-soaked lesions (cellular necrosis) were the only indicators of fungal growth; however, mycelia developed on the carrots after removal from the ozonated atmospheres.

Growth rates of $B$. cinerea and $S$. sclerotiorum increased with temperature, with most of the increase occurring between 2 and $8 \mathrm{C}$ (Table 2). A trend of decreased growth rate with increased ozone concentration was observed within each storage temperature. The growth rate for $B$. cinerea at 2,8 , and $16 \mathrm{C}$ at $60 \mu l \cdot$ liter $^{-1}$ ozone was $43 \%$ to $58 \%$ of the respective control treatment.

Although growth rate of $S$. sclerotiorum increased with storage temperature, the magnitude of the increase was reduced with higher ozone concentration (Table 2). The growth rate of $S$. sclerotiorum at 2, 8, and $16 \mathrm{C}$ was reduced to between $44 \%$ to $63 \%$ at $60 \mu \mathrm{l} \cdot$ liter $^{-1}$ compared with the respective control treatments. The lower linear and quadratic regression coefficients at 2C for $S$. sclerotiorum than at 8 and $16 \mathrm{C}$ suggests that the higher residual ozone concentration at $2 \mathrm{C}$ (Table 1 ) could have caused a greater reduction in fungal growth rate than those observed at 8 and $16 \mathrm{C}$. This effect was not observed for $B$. cinerea.

Physiology. Ozone did not affect carrot weight loss (data not presented). Carrot respiration rate at $9 \mathrm{C}$ generally increased with ozone concentration, with a mean ranging from $18.2 \mathrm{mg} \mathrm{CO}_{2} / \mathrm{kg}$ per $\mathrm{h}$ in the control to $20.7 \mathrm{mg} \mathrm{CO} / \mathrm{kg}$ per h at $60 \mu \mathrm{l} \cdot \mathrm{liter}^{-1} \mathrm{ozone}$ (Table 3). Even though the respiration rate was higher in carrots treated with ozone, carrot leaves, which appeared at 8 and 16C, were fewer, shorter, and necrotic in the treatments receiving ozone (data not shown). The presence of carrot leaves decreased with increasing ozone concentration.

Ozone treatment increased electrolyte leakage from $37.4 \%$ in the control to $48.8 \%$ at $60 \mu \mathrm{l} \cdot \mathrm{liter}^{-1}$ ozone. The highest electrolyte leakages occurred at 2 and $8 \mathrm{C}$. The linear regression coefficient at $16 \mathrm{C}$ was lower than at 2 and $8 \mathrm{C}$ and could be caused by the existence of higher residual ozone concentrations at the two lower temperatures (Table 1).

Visual observations of carrots agreed with the results of electrolyte leakage. Carrot surfaces in ozone treatments were pitted with dry white blotches, which intensified with increas-

Table 1. The effect of temperature and ozone supply on residual concentration.

\begin{tabular}{lllccc}
\hline \hline Temp & \multicolumn{5}{c}{ Ozone supply $\left(\mu 1 \cdot\right.$ liter $\left.^{-1}\right)$} \\
\cline { 2 - 6 }$\left({ }^{\circ} \mathrm{C}\right)$ & 0 & 7.5 & 15 & 30 & 60 \\
\hline 2 & 0 & 1.0 & 3.1 & 10 & 22 \\
8 & 0 & 1.0 & 3.0 & 6.7 & 20 \\
16 & 0 & 0.6 & 1.8 & 3.0 & 18 \\
\hline
\end{tabular}


Table 2. Daily growth rate of Botrytis cinerea and Sclerotinia sclerotiorum on carrots at different temperatures and ozone concentrations in storage.

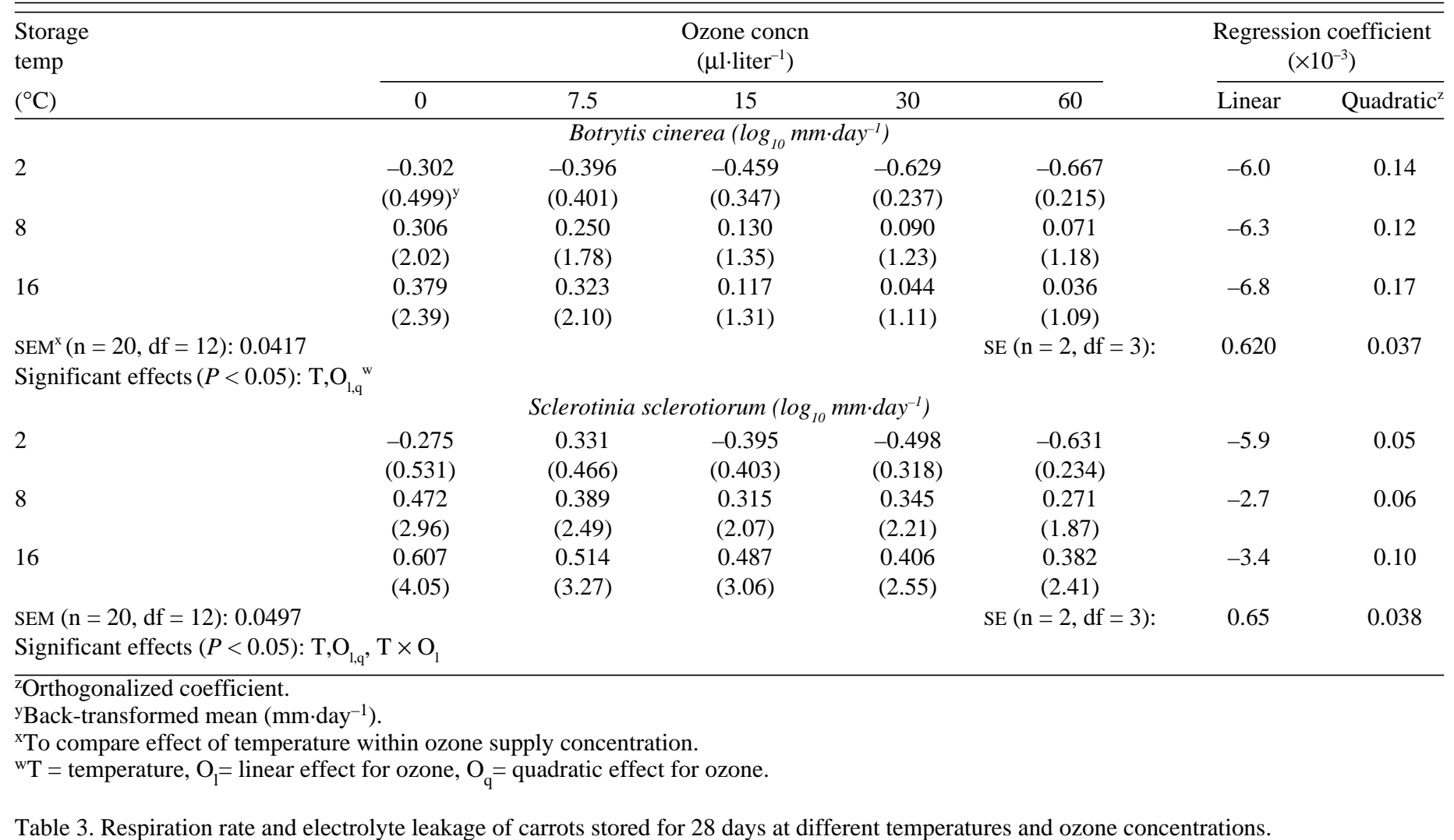

\begin{tabular}{|c|c|c|c|c|c|c|}
\hline \multirow{2}{*}{$\begin{array}{l}\text { Storage } \\
\text { temp } \\
\left({ }^{\circ} \mathrm{C}\right)\end{array}$} & \multicolumn{5}{|c|}{$\begin{array}{c}\text { Ozone supply concn } \\
\left(\mu 1 \cdot \text { liter }^{-1}\right)\end{array}$} & \multirow{2}{*}{$\begin{array}{l}\text { Regression coefficient } \\
\left(\times 10^{-2}\right) \\
\text { Linear }\end{array}$} \\
\hline & 0 & 7.5 & 15 & 30 & 60 & \\
\hline \multicolumn{7}{|c|}{ Respiration rate $\left(\mathrm{mg} \mathrm{CO}_{2} / \mathrm{kg} \mathrm{per} \mathrm{h}\right)^{z}$} \\
\hline 2 & 11.4 & 11.4 & 13.4 & 16.8 & 15.3 & 0.75 \\
\hline 8 & 19.7 & 17.3 & 18.2 & 17.8 & 22.8 & 0.65 \\
\hline 16 & 23.4 & 23.5 & 20.4 & 21.6 & 24.2 & 0.16 \\
\hline $\operatorname{SEM}^{\mathrm{y}}(\mathrm{n}=2, \mathrm{df}=12): 2.21$ & & & & & $\operatorname{SE}(n=2, d f=3)$ : & 0.344 \\
\hline Significant effects $(P<0.05)$ : $\mathrm{O}_{1}{ }^{\mathrm{w}}$ & & & & & & \\
\hline \multicolumn{7}{|c|}{ Electrolyte leakage (\%) } \\
\hline 2 & 39.3 & 44.2 & 41.3 & 43.2 & 53.2 & 20.8 \\
\hline 8 & 36.3 & 42.6 & 41.4 & 43.6 & 53.1 & 24.6 \\
\hline 16 & 36.6 & 36.9 & 36.3 & 40.8 & 40.0 & 7.1 \\
\hline $\begin{array}{l}\text { SEM }(\mathrm{n}=10, \mathrm{df}=12): 3.38 \\
\text { Significant effects }(P<0.05): \mathrm{O}_{1}, \mathrm{~T} \times \mathrm{O}_{1}\end{array}$ & & & & & $\mathrm{SE}(\mathrm{n}=2, \mathrm{df}=3)$ : & 2.7 \\
\hline
\end{tabular}

${ }^{\mathrm{z}}$ Respiration rate is the mean of five daily measurements at 9C.

yTo compare effect of temperature within ozone supply concentration.

${ }^{\mathrm{w}} \mathrm{T}=$ temperature, $\mathrm{O}_{1}=$ linear effect for ozone.

ing ozone concentration. Visible injury in the form of brown water-soaked lesions also appeared on carrot leaves treated with the highest ozone concentration at $2 \mathrm{C}$.

The normal orange-red surface color of carrots appeared to be bleached on ozone-treated carrots. This was reflected in mean $\mathrm{L}^{*}$ values, which increased from 49.6 in the control to 52 at an ozone concentration of $60 \mu \mathrm{l} \cdot$ liter $^{-1}$ (Table 4). Ozone also affected the intensity of carrot color. Mean chroma values of 30.2 in the control decreased to 28.7 at $60 \mu \mathrm{l} \cdot$ liter $^{-1}$ ozone (Table 4). Although not significant, the decrease in mean chroma was greatest at $2 \mathrm{C}$, followed by 8 and 16C. Although hue was unaffected by the ozone treatments, higher hue values were obtained at a storage temperature of $8 \mathrm{C}$ (Table 4). Mean total color differences in the control increased from 4.2 to 6.6 when treated with an ozone concentration of $60 \mu \mathrm{l} \cdot$ liter $^{-1}$ (Table 4 ).

\section{Discussion}

Although some storage studies have reported ozone concentrations as residual ozone (Schomer and McCulloch, 1948; Spalding, 1968), experiments using residual ozone concentration may not be appropriate since residual ozone concentration may be affected by temperature and reactivity of exposed materials. Ewell (1933) reported that applying 1 ppm ozone to produce such as eggs, apples, and beef (with similar amounts of surface area) resulted in different residual ozone concentrations. This study indicated that 
Table 4. Lightness, chroma, hue and total color difference of carrots stored for 28 days at different temperatures and ozone concentrations.

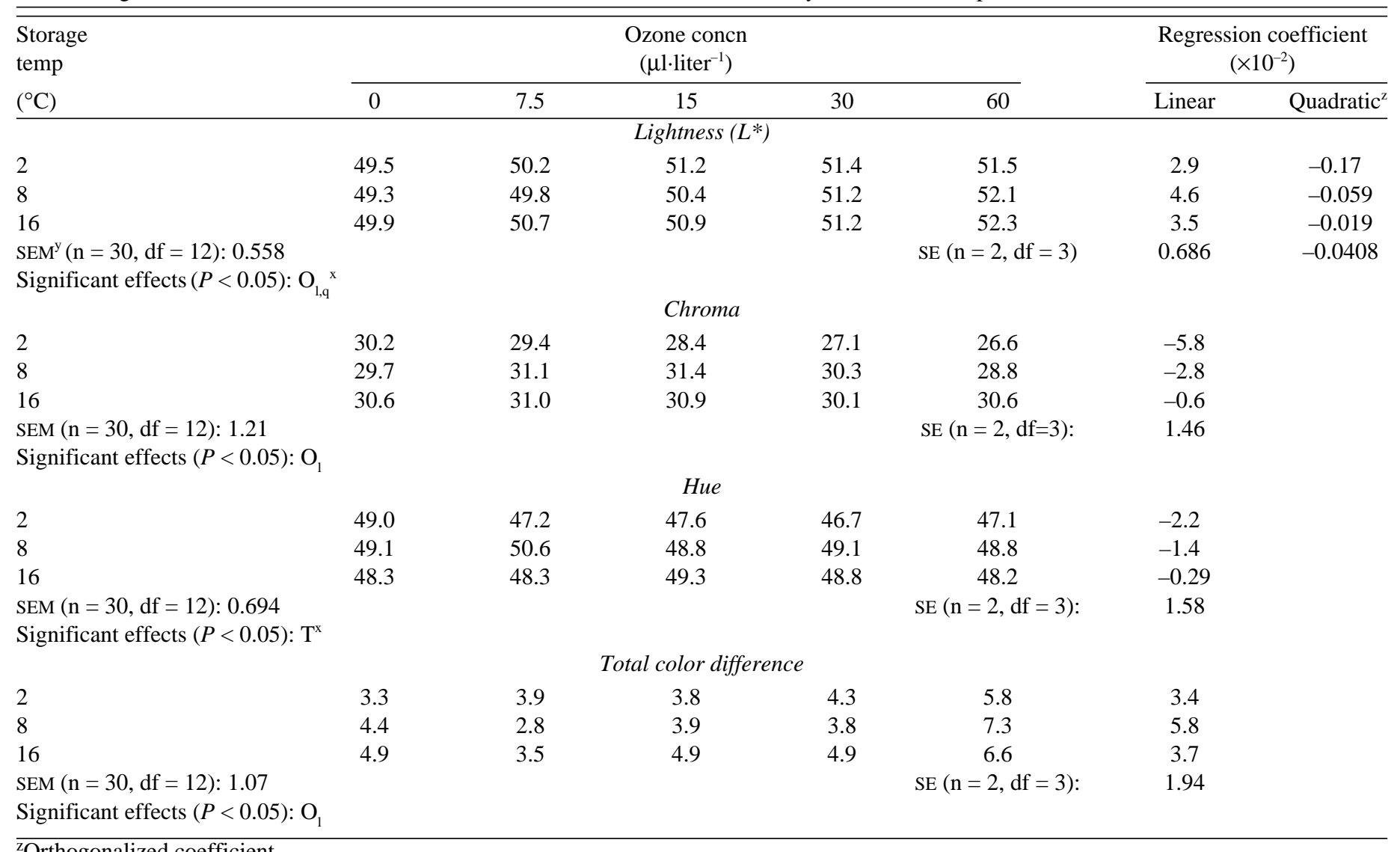

Orthogonalized coefficient.

yTo compare effect of temperature within ozone supply concentration.

${ }^{\mathrm{x}} \mathrm{T}=$ temperature, $\mathrm{O}_{\mathrm{l}}=$ linear effect for ozone, $\mathrm{O}_{\mathrm{q}}=$ quadratic effect for ozone.

the residual concentration was influenced by temperature. Increasing the storage temperature would increase the amount of ozone required to maintain a specific residual concentration. Therefore, maintaining a constant residual ozone concentration over a storage period will require adjustments in the amount of ozone supplied. These adjustments could be made with an automated gas control system to maintain gas concentrations, such as the ozone application and measurement systems frequently used by environmental and pollution researchers (Hale-Marie et al., 1991).

Our results suggest that the efficacy of ozone as a disinfectant must be individually assessed for each commodity at its ideal storage temperature. Furthermore, the quantity of produce in storage and the system available for dispensing and measuring ozone must be considered.

The effect of ozone on B. cinerea and S. sclerotiorum was fungistatic and not fungicidal. Although some inhibitory effects were observed with ozone residual concentrations of 10 to 22 $\mu \mathrm{l} \cdot \mathrm{liter}^{-1}$ at $2 \mathrm{C}$, these concentrations seemed to cause physical and physiological damage to carrots. Symptoms of physiological disruptions included increased respiration rates, electrolyte leakage, and color changes. Higher respiration rates with increasing ozone concentrations are likely an expression of abnormal metabolism or injury caused by ozone to the carrots. Further, alterations in appearance of ozone-treated carrots due to color changes and surface pitting may affect consumer appeal.

The results of this study agree with other studies that have examined the effects of ozone on plants (Beckerson and Hofstra, 1980; Frederick and Heath, 1975; Hewitt et al., 1990; Sakaki et al., 1983; Tomlinson and Rich, 1970). These studies demonstrated that plants exposed to ozone have higher electrolyte leakage compared with control plants (no ozone) and are subjected to pigment destruction (chlorophyll a and carotenoids). Some researchers have speculated that ozone causes some form of lipid peroxidation in the plant cells, a result suggesting that membrane lipids are susceptible to ozone damage. In addition, physiological disruptions to plant tissue caused by ozone treatment may also result in losses of organic and inorganic nutrients.

If ozone is to be used for carrot storage, a balance must be found between preserving carrot quality and effective disease control. This study has demonstrated that reducing temperature from 16 to $2 \mathrm{C}$ significantly reduced fungal growth of nonozonated carrots. Immediate ozonation may be unnecessary if carrots are properly harvested, washed, hydro-cooled, and cold-stored at the appropriate temperature. Although commercial carrot storages have air temperatures between 0 and $1 \mathrm{C}$, carrots stored in large bins may build up pockets of heat in the middle of the bins during long storage periods. These heat pockets are prime areas for fungal growth and development. It is often the combination of reduced resistance to infection by the carrots and poor heat removal that encourages pathogen proliferation. With proper air circulation and temperature control, ozonation may be introduced in the latter part of the storage period, when carrots are less resistant to fungal attacks (Goodliffe and Heale, 1978; Harding and Heale, 1980). Even at low temperatures, diseases can spread by mycelial growth and spore production. Since carrot diseases often spread from one root to the next from a focus of infection or from contaminated storage bins, reducing surface fungal growth with ozone 
may limit the spread of pathogens. Based on our results, an ozone supply of $15 \mu \mathrm{l} \cdot \mathrm{liter}^{-1}$ for $8 \mathrm{~h}$ a day at $2 \mathrm{C}$ could provide some disease protection with a minimum of physical and physiological damage.

\section{Literature Cited}

Barger, W.R., J.S. Wiant, W.T. Pentzer, A.L. Ryall, and D.H. Dewey. 1948. A comparison of fungicidal treatments for the control of decay in California cantaloupes. Phytopathology 38:1019-1024.

Beckerson, D.W. and G. Hofstra. 1980. Effects of sulphur and ozone, singly or in combination, on membrane permeability. Can. J. Bot. 58:451-457.

Brooks, R.I. and A.S. Csallany. 1978. Effects of air, ozone, and nitrogen dioxide exposure on the oxidation of corn and soybean lipids. J. Agr. Food Chem. 26:1203-1209.

Ewell, A.W. 1933. Decomposition of ozone. Refrigeration Eng. 26:6869.

Frederick, P.E. and R.L. Heath. 1975. Ozone induced fatty acid viability changes in Chlorella. Plant Physiol. 55:15-19.

Gibson, C.A., J.A. Elliot, and D.C. Beckett. 1960. Ozone for controlling mold on cheddar cheese. Can. Dairy and Ice Cream J. (Dec.):24-28.

Gnanasekharan, V., R.L. Shewfelt, and M.S. Chinnan. 1992. Detection of color changes in green vegetables. J. Food Sci. 57:149-154.

Goodliffe, J.P. and J.B. Heale. 1978. The role of 6-methoxymellein in the resistance and susceptibility of carrot root tissue to the cold storage pathogen Botrytis cinerea. Physiol. Plant Pathol. 12:27-43.

Guinvarch, P. 1959. Ozone chemistry and technology. Adv. Chem. Ser. 21. Amer. Chem. Soc., Wash., D.C. p. 416-430.

Hale-Marie, B., R.G. Dutton, O.B. Allen, D.P. Omrod, S.N. Goodyear, and L.G. Pyear. 1991. Design and verification of a programmable gas dispensing system for exposing plants to dynamic concentrations of air pollutants. J. Air Waste Mgt. Assn. 41:460-463.

Harding, V. and J.B. Heale. 1980. Isolation and identification of the antifungal compounds accumulating in the induced resistance response of carrot root slices to Botrytis cinerea. Physiol. Plant Pathol. 17:277289.

Hewitt, C.N., G.L. Kok, and R. Fall. 1990. Hydroxyperoxides exposed to ozone mediate air pollution damage to alkene emitters. Nature 344:5658.
Kashiwagi, Y., T. Ueta, Y. Tsuchiya, H. Ichikawa, and M. Kazama. 1987. Studies on sterilization with ozone gas. Annu. Rpt. Tokyo Metropolitan Res. Lab. of Public Health 38:22-27.

Lide, D.R. (ed.). 1991. CRC Handbook of chemistry and physics. 2nd ed. CRC Press, Boca Raton, Fla. Section 16, p. 16.

Little, A.C. 1975. Off on a tangent. J. Food Sci. 40:410-411.

Naito, S. 1989. The influence of ozone treatment on lipids contained in cereal grains, cereal grain powders, peas, beans and pulse products. Nippon Shokuhin Kogyo Gakkaishi 36:878. (Abstr.)

Norton, J.S., A.J. Charig, and I.E. Demoranville. 1968. The effect of ozone on storage of cranberries. Proc. Amer. Soc. Hort. Sci. 93:792796.

Ogawa, J.M., A.J. Feliciano, and B.T. Manji. 1990. Evaluation of ozone as a disinfectant in postharvest dumptank treatments for tomato. Phytopathology 80:1020. (Abstr.)

Payne, R., P. Lane, A. Ainsley, K. Bicknell, P. Digby, S. Harding, P. Leech, H. Simpson, A. Todd, P. Verrier, R. White, J. Gower, G. Wilson, and L. Paterson. 1988. Genstat 5 reference manual. Oxford Univ. Press, New York.

Prange, R.K. and P.D. Lidster. 1991. Controlled atmosphere and lighting effects on storage of winter cabbage. Can. J. Plant Sci. 71:263-268.

Rice, R.G., J.W. Farquhar, and J.L. Bollyky. 1983. Review of the applications of ozone for increasing storage times of perishable goods. Proc. 6th Ozone World Congr. Intl. Ozone Assn. p. 41-44.

Rosenthal, H. and J.S. Wilson. 1987. An up-dated bibliography (18451986) on ozone, its biological effects and technical applications. Dept. of Fisheries and Oceans. Can. Tech. Rpt. Fisheries and Aquatic Sci. 1542.

Sakaki, T, N. Kondo, and K. Sugahara. 1983. Breakdown of photosynthetic pigments and lipids in spinach leaves with ozone fumigation: Role of active oxygens. Physiol. Plant. 59:28-34.

Schomer, H.A. and L.P. McCulloch. 1948. Ozone in relation to storage of apples. U.S. Dept. of Agr. Circ. 765.

Sheldon, B.W. and A.L. Brown. 1986. Efficacy of ozone as a disinfectant for poultry carcasses and chill water. J. Food Sci. 51:305-309.

Spalding, D.H. 1968. Effects of ozone atmospheres on spoilage of fruits and vegetables after harvest. U.S. Dept. of Agr. Mktg. Res. Rpt. 801.

Tomlinson, H. and S. Rich. 1970. Lipid peroxidation. A result of injury in bean leaves exposed to ozone. Phytopathology 60:1531-1532.

Torricelli, A. 1959. Ozone chemistry and technology. Adv. Chem. Ser. 21. Amer. Chem. Soc., Wash. D.C. p. 375-380.

Whistler, P.L. and B.W. Sheldon. 1989. Bactericidal activity, eggshell conductance and hatchability effects of ozone versus formaldehyde disinfection. Poultry Sci. 68:1074-1077.

Yang, P.P.W. and T.C. Chen. 1979. Stability of ozone and its germicidal properties on poultry meat microorganisms in liquid phase. J. Food Sci. 44:501-504. 